\title{
A SYSTEMIC APPROACH TO THE MANAGEMENT OF MUSEUM HERITAGE: THE CASE OF BASILICATA REGION MUSEUM POLE (ITALY)
}

\author{
Sonia Ferrari ${ }^{1}$ \\ Nicolaia Iaffaldano ${ }^{2}$ \\ Vito Roberto Santamato ${ }^{3}$
}

DOI: https://doi.org/10.31410/ITEMA.2019.27

\begin{abstract}
The main aim of this paper is the definition of the distinctive features of museum networks and systems with a focus on the potential of specific organizational and management solutions in terms of optimization of museums' effectiveness and efficiency, especially in Italy.

Research regarding the Museum Pole of the Basilicata Region (MPBR) in Southern Italy will be presented. The MPBR is recognized as a successful and innovative form of large-scale (compatible with the limited size of the region) sharing of strategies, services, organizational structures, cultural planning, scientific contents, and technical and administrative tools, also following the nomination of Matera as 'European Capital of Culture 2019'. The research is based on existing data and qualitative interviews with the MPBR management and other stakeholders.
\end{abstract}

Keywords: Museum Network, Museum System, Systematic Approach.

\section{INTRODUCTION}

$\mathrm{T}$ hanks to the rise over the last decades in Italy of a large number of museum networks and systems, although with very different characteristics from each other, the systemic approach to museum heritage management has been brought to the attention of scholars, especially in the economic, business and management fields. Reticular organizational structures and management models based on the systemic perspective have also been formally recognized as the best solutions to optimize the effectiveness and efficiency of museums, especially in Italy. In fact, Italian museums are mostly small, widely scattered all over the territory and mainly of local interest. In addition, they are burdened by heavy internal financial, organizational and productive constraints.

The main aim of this paper is the definition of the distinctive features of museum networks and systems with a focus on the potential of specific organizational and management solutions in terms of the optimization of museums' effectiveness and efficiency. For this purpose, the business, economics and management literature will the basis to outline the theoretical framework, with particular reference on the one hand to the business networks and, on the other hand, to the characteristics of the Italian museum heritage. Subsequently, the attention will be focused on the implementation of museums reticular structures and on their management in a systemic approach.

1 University of Calabria, Department of Business and Law Science, Campus di Arcavacata, 87036, Rende (Cs), Italy

2 University of Bari, Ionian Department of Law, Economics and Environment, Via Lago Maggiore ang. Via Ancona, 74121, Taranto, Italy

3 University of Bari, Department of Economics, Management and Business Law, Largo Abbazia Santa Scolastica, 70124, Bari, Italy 
In particular, the paper aims to:

- clarify the distinctive features of museum networks and systems, considering the paradigms of the vital systemic approach;

- identify the main probable advantages achievable through the implementation of these solutions, also considering the literature that postulates the integrated enhancement of the territory and its cultural resources for the creation of innovative tourist routes. These routes would be richer in terms of capillarity and significance compared to the common tourist routes. In addition, this perspective would make it possible to obtain a more adequate spatial and temporal distribution of the tourist flows in order to achieve economic, social and cultural sustainability;

- indicate the most appropriate methods for implementing and operating museum networks and systems;

- identify the most critical issues with regard to Italian experiences.

Research regarding the Museum Pole of the Basilicata Region (MPBR), in Southern Italy, will be presented. The MPBR is recognized as a successful and innovative form of large-scale (compatible with the limited size of the region) sharing of strategies, services, organizational structures, cultural planning, scientific contents and technical and administrative tools, also following the nomination of Matera as ,European Capital of Culture 2019'. The research is based on existing data and qualitative interviews with the MPBR management and other stakeholders.

\section{LITERATURE REVIEW}

The post-modern change in the socio-economic context, with particular regard to market conditions, has led companies to modify their productive and competitive strategies towards an inter-company and network cooperation (Albertini, 1990; Lorenzoni, 1897; 1990; 1992; Mariti, 1980). As a consequence, starting from the last twenty years of the twentieth century, inter-organizational structures have been spontaneously experimented by small Italian companies. In the current era of the experience economy (Pine \& Gilmore, 2000), the network is becoming the most widespread form of production and consumption (Rullani, 2008; Thorelli, 1986; Vacca, 1986; Vicari, 2008).

In the literature the terms "museum network" and "museum system" are not clearly defined. Therefore, it seems appropriate to propose, even if briefly, a differentiation between these terms referring to the paradigms of the vital systemic approach (Golinelli, 2011). A museum network can be defined as a structural arrangement produced by the establishment of cooperative ties among several museum organizations, or the set of museum-components and the relationships between them. In a holistic perspective, a museum system can be seen as a management structure: it will originate when some of the pre-set relationships between the museums of the network are actually implemented to achieve a specific objective. The museum system can therefore be defined as a structure-network of active museums. Therefore, multiple systems (or sub-systems) can emerge from a museum network, depending on the specific activity that they aim to carry out jointly. It should be noted that the term network will be used to indicate systemic management models based on network organizational structures (Golinelli, 2012; Iaffaldano \& Mariella, 2014; Montella, 2003 and 2009).

From a cultural point of view, the Italian museum collections are mutually complementary because they come from places that are culturally cohesive and widely spread throughout the 
territory. For this reason, the networks are decisive in making explicit the most important historical connections between the collections of each museum and between these and the territorial context. This is also the prerequisite for developing landscape enhancement policies, according to an integrated and systemic approach, so as to capture the strategic value of places (Bonel et al., 2005; Ferrari, 2013; Ferrari \& Gilli, 2015; Franch, 2002; Gregori, 2005; Iaffaldano, 2013; Cirillo, 2016; Johnson et al., 2015; Martini, 2005; Pencarelli \& Splendiani, 2008; Soren, 2009). A satisfactory experience of places needs to be facilitated with routes offered thanks to special tools; they could be the Italian museums thanks to their widespread diffusion and local character. The strategy of the museum-territory could be very useful for this purpose (Dragoni, 2005; Montella, 2003).

Also the recommendations of the Italian ministerial decrees move this direction in that they face the theme of the relationship between museums and territory warning that "the territory as a widespread museum [ ...] can be enjoyed and respected only if it finds in the museum-institute a suitable location for the interpretation and communication of its values" (DM May 10, 2001). Also, the International Cultural Tourism Charter: Managing Tourism at Places of Heritage Significance (ICOMS, Paris 1999) pursues the enhancement of systems for the management of cultural heritage to make single and overall meanings accessible to users ( $\mathrm{Hu}, 2019)$.

Moreover, the networks seem to be indispensable to overcome the financial, organizational and productive constraints and the structural economic limits due to the low number of visitors (Bagdadli, 1995, 1997 and 2001). Indeed, it could help to achieve decisive economies of scale, as well as saturation, specialization and learning economies. At the same time, the network would make it possible to achieve objectives linked to differentiation strategies. It would be particularly effective for the implementation of differentiated marketing policies to intercept the multiple interests that move the different clusters of demand and, therefore, to attract more and more visitors. With reference to the promotional activities, the network would allow the prestige to increase and also enhance the image of the whole and of each museum-component (Bollo, 2012; Zan, 1999).

\section{THE BASILICATA REGION MUSEUM POLE RESEARCH METHODOLOGY}

The MPRB has been analyzed as a particularly interesting case with respect to the research objectives of the paper. This case, that has been recognized by many as a successful and innovative form of large-scale sharing of strategies, services, organizational set-ups, cultural addresses, scientific contents, and technical and administrative tools, therefore, seems to be a model. From this case it could be possible to obtain appropriate design and implementation suggestions.

A qualitative empirical investigation responding to exploratory aims has been carried out by the authors with the aim of providing a description of the composition process, the functioning and the results achieved by the museum system, with a focus on its main strengths.

The analysis of the case was first conducted by reviewing the main studies on the subject in the literature (Bagdadli, 1997; Cabasino \& Trimarchi, 1997; Gioli, 2001; Pezzoni \& Vago, 2000). The information acquired was then integrated analyzing institutional documents and conducting in-depth interviews with stakeholders - operators in the tourism and cultural heritage sectors. This approach was chosen because the qualitative method is more interactive, in-depth and sensitive in the study of human behaviour, attitudes, ways of thinking and motivations. The 
survey was based on 10 in-depth face-to-face and semi-structured interviews, each lasting between 40 and 60 minutes. All interviews were recorded and transcribed the same day to ensure minimal information loss. A subsequent step was to structure meanings using narrative, leaving the stories of participants as they were told.

Data analysis followed a deductive coding approach. The data were managed by hand through a thematic analysis. The three main themes identified are as follows:

- how MPRB was born and has evolved,

- impact of the nomination of Matera as2019 European Capital of Culture (ECC) on the MPRB,

- effects of the new management method on MPRB operational results.

These themes are useful to study the main objects of our research.

\section{FINDINGS AND DISCUSSION}

\subsection{How the MPBR was born and has evolved}

As in all Italian regions, the MPBR was born thanks to the Franceschini Reform between 2014 and 2015 (Marzano \& Castellini, 2018). Coordinated by the Directorate General of Museums, the Pole is the connection point between the center and the periphery; it aims to foster the dialogue between state and local authorities and between public and private museums for the construction of the regional museum system. The MPBR coordinates human, technological and financial resources of various museums in order to offer the public cultural and exhibition activities, quality reception and educational services. It supports the creation of local networks, that involve different actors for the development of cultural itineraries and the growth of the territory.

The PMRB is one of the smallest but also one of the most homogeneous Italian poles. The network is mainly composed of archaeological museums (8) and also by other important but smaller museums, and an exhibition site in the Ducal Palace of Tricarico. The core of this homogeneous network is the National Museum of Medieval and Modern Art in Palazzo Lanfranchi, that is a historical-artistic museum. It was, as one interviewee tells us, the fulcrum of the process of appointment of Matera as European Capital of Culture 2019.

The work preceding the birth of the Pole was carried out around this museum (36,833 visitors in the year 2018). This museum has strategically chosen to open itself to the community. This truly new methodology represented the basis of the Matera-Basilicata 2019 Foundation (which handled the entire candidature process). In the first years of building the candidature it was a scientific and operational committee. This method of openness, total accessibility, involvement, participation, and concrete work with the community was immediately shared by the other stakeholders and it was, as one interviewee explains, the distinctive trait for the construction and then the implementation of the candidacy, of Matera-Basilicata 2019. Another interviewee adds that: the networking process began with some events, the week of culture, the night of the museums, the day of the landscape, creating a coordinated program with all or almost all the museums. We involved associations and protagonists of local cultural life in this program. Therefore, the MPBR museums can be considered as museums of the territory, or museums that can intersect the interest of the major stakeholders with those of local community. 
Regarding the existence of networks of operators in Matera, four of the interviewees confirm that there are several collaborative networks in different sectors. However, we are told by one of them that, there is not a large intersectoral network. In particular, there are many micro-networks that work and others that do not work. In tourism, specifies another, a network is needed. However, adds one interviewee, there is not a subject able to coordinate all the promotional activities.

The individualism of the various subjects cannot be overcome. Each subject has its own cartel, formed by other subjects that act as its satellites; the networks are not created among peers, one of the interviewees complains.

\subsection{Impact of the nomination of Matera as 2019 European Capital of Culture (ECC) on the MPRB}

In 2018 the visitors of the MPBR were 262,000, with revenues of 219,000 Euros. These data are defined as "very positive" by the Pole management, and they confirm the boom in visitors registered in Matera in the previous year.

The extraordinary challenge and the notable responsibility were not only of those who led the process of creation of the network, but also of all the institutions that joined them to achieve the result. According to one interviewee, it became a shared cultural working method.

The objective of creating a museums network in a small, limited and homogeneous environment such as that of Basilicata could be concretized, while elsewhere it would be much more diffcult. Museum Poles with 40, 45 or 50 museums, in fact, cannot really put their structures into a network, because they are different and scattered, they have heterogeneous needs, perspectives and problems. Instead, with the exception of Palazzo Lanfranchi, our museums are more homogeneous. The latter, however as one of the interviewees explains, was easily included in the network having been the engine of the whole process.

The network was the element that led to the nomination of Matera. The ECC recognition was obtained by the whole region, by all the 130 municipalities in the region, but also by the neighboring regions, Puglia, Calabria, and Campania, he/she goes on.

But the network was not born only thanks to the nomination: it was the result of the Franceschini Reform, which aims at the concrete realization of the National Museum System, says an interviewee. And he/she adds: So, a certain direction, that of the network, had already been started and it was easy then with the arrival of the new collaborators, archaeologists and architects to build a wider team. The main part of the ECC program was carried out together with the MPBR.

As for the legacy of the ECC event, one of the interviewees says something very important: We adopted a new method and way of thinking, which is now the task of all those who live in our area to carry on.

\subsection{Effects of the new management method on MPRB operational results}

Our museums have no autonomy in any sense, so the MPRB is the main subject in the organization and management of the activities. Being a Pole allows us to achieve certain results, we are told. An interviewee says: Many museums in Basilicata cannot be autonomous because they draw just a few 
tens of thousands of Euros a year. The museums are managed with a portfolio logic and the Pole acts as the implementing entity for the activities that each museum carries out. The expenses of the museums are in charge of the Pole, which collects the revenues. The efficiency and effectiveness of the system are, however, limited by bureaucratic problems and lack of personnel.

The strategic programming is common. The result is that, we are told, every museum has a different positioning, a precise identity, but the objective is not to increase the revenues, an interviewee says.

The museums of the Basilicata Region have been set up and proposed to the public not as treasure chests in themselves, but as episodes of a story that continues in the city and in the territory, as a door through which to introduce the visitor to the uninterrupted diffuse museum, in which the real Italian competitive advantage consists. To this end, the museum-territory strategy was implemented and considered decisive for the systemic enhancement of the historical-cultural heritage of the Basilica, the management of the Pole explains. However, there are no joint tickets and shared price policies. In addition, the museums do not have online reservations or forms of collaboration with tour operators.

To complete this picture about the BRMP, we must add that some of the interviewees stress that these territories cannot accommodate large flows of visitors, there is the risk of overtourism and a potential lack of tourism sustainability. There is a pressure on the Murgic plateau, rich in rock churches; they cannot anthropize the area of the plateau, one of the interviewees explains.

\section{CONCLUSION}

The paper presents findings that have implications both at a theoretical and a managerial level. In fact, it illustrates the peculiar characteristics of the Italian museum heritage and aims to focus on the potentially achievable advantages related to the adoption of the network as organizational solution and to the implementation of its systemic management. The MPBR case is illustrated as an empirical finding of the theoretical reflections. It is recognized by many as a successful and innovative form of large-scale sharing of strategies, services, organizational structures, cultural addresses, scientific contents, and technical and administrative instrumentation.

The study highlights that the network could allow Italian museums, that are widespread throughout the territory, mainly of local interest and burdened by heavy internal constraints, to optimize management effectiveness and efficiency. The network can reduce the production costs, enhance the overall production capacity and increase the qualitative and quantitative level of the offer. The Pole museums can attract a growing number of visitors and achieve significant economies of scale. As a consequence, it could obtain important plant and business costs reductions and revenue increases.

Furthermore, network museums could make their cultural heritage more accessible, not limiting their value to the aesthetic-formal aspect. This could happen because the network significantly helps to make explicit the historical connections between the objects of each museum and between them and the context of origin, presenting them to the public as material testimonies of the culture spread in a certain time and place. It is legitimate to expect from this information-educational function the increase in the human capital of visitors, the strengthening and the dissemination of the community identity and, therefore, a greater fulfillment of the public func- 
tion of Italian museums. At the same time, the network could allow each museum to strengthen its image and to make use of the integrated product created to better intercept the multiple interests of the different demand clusters and, therefore, to attract an ever-increasing number of visitors. Finally, the entire territory would be enhanced and a support for marketing and place branding policies would be offered.

The study presents a model for the establishment of a regional museum network and for its management in a systemic perspective. In the future, this could become a reference model to provide public decision makers in the cultural sector with useful suggestions related to the design and development of such processes.

\section{REFERENCES}

Albertini, S. (1990). Modello «strategia-risorse-strategia» e forme di coordinamento a rete. Economia e Politica Industriale, 65, 147-180.

Bagdadli, S. (1995). Cooperazione o isolamento? Verso una nuova organizzazione dei musei italiani. Economia \& Management, 7, 110-121.

Bagdadli, S. (1997). Il museo come azienda. Management e organizzazione al servizio della cultura. Milano: Etas Libri.

Bagdadli, S. (2001). La rete di musei. L'organizzazione a rete per $i$ beni culturali in Italia e all'estero. Milano: Egea.

Bollo, A. (2012). Il marketing della cultura. Roma: Carocci.

Bonel, E., Moretti, A., Rispoli, M., \& Tamma, M. (2005). I prodotti culturali in una prospettiva economico-manageriale. Economia della Cultura, 4, 497-512.

Cabasino, E., \& Trimarchi, M. (1997). Musei e territorio: archivi della memoria storica e poli di sviluppo e di comunicazione culturale in Europa. Economia della Cultura, 2, 146-149.

Cirillo, N. (2016). An integrated approach to the valorization strategy of cultural heritage. In: F. Bifulco \& T. Russo Spena (Eds.). Managing cultural heritage. Milano: McGraw-Hill.

Dragoni, P. (2005). Antimarketing dei musei italiani? Sinergie, 23 (68), 55-73.

Ferrari, S. (2013). An experiential approach to differentiating tourism offers in cultural heritage. In: M. Smith, \& G. Richards (Eds). Routledge Handbook of Cultural Tourism. Oxon, UK: Routledge, 383-388.

Ferrari, S., \& Gilli, M. (2015). From the Museums of Objects to the Virtual Museums: An Opportunity for Local Tourism Development. In H. Eto (Ed.). New Business Opportunities in the Growing E-Tourism Industry. Hershey, Pennsylvania (USA): IGI Global Publication: 255-272.

Franch, M. (a cura di). (2002). Destination management. Governare il turismo tra locale e globale. Torino: Giappichelli.

Gioli, A. (2001). Les musées italiens entre le public et le privé. In AA.VV., L'avenir des musées, Réunion des musées nationaux-musée du Louvre, Paris.

Golinelli, G.M. (2011). L'approccio sistemico vitale al governo dell'impresa. Vol. II Verso la scientificazione dell'azione di governo, Padova: Cedam.

Golinelli, G.M. (a cura di). (2012). Patrimonio culturale e creazione di valore. Padova: Cedam. Gregori, G.L. (2005). Quali soluzioni tecnico-organizzative per il soddisfacimento di una domanda 'integrata' di turismo: dai sistemi turistici locali al franchising territoriale. Sinergie, 23 (66), 55-77.

$\mathrm{Hu}$, J. (2019). Exploration on the Development Direction of Museum Management in the New Period. Management Science and Research, 8, 109-112. 
Iaffaldano, N. (2013). Il 'museo diffuso' e le risorse immateriali quali determinanti della competitività di una destinazione turistica culturale. Esperienze d'Impresa, 2, 43-67.

Iaffaldano, N., \& Mariella, G. (2014). The proposal of a model to build a museum network and its management in a systemic perspective in Apulia. In conference book proceedings of the $17^{\text {th }}$ Toulon-Verona Conference Excellence in Services, Liverpool John Moores University, Liverpool, England, August 28-29, 2014, pp.179-196.

Johnson, L., Becker, S. A., Estrada, V., \& Freeman, A. (2015). NMC horizon report: 2015 museum edition. The New Media Consortium.

Lorenzoni, G. (1987). Costellazioni di imprese e processi di sviluppo. Sviluppo e Organizzazione, 102, 59-72.

Lorenzoni, G. (1990). L'architettura di sviluppo delle imprese minori. Bologna: Il Mulino.

Lorenzoni, G. (ed.). (1992). Accordi, reti e vantaggio competitivo. Le innovazioni nell'economia d'impresa e negli assetti organizzativi. Milano: Etas Libri.

Mariti, P. (1980). Sui rapporti tra imprese in un'economia industriale moderna. Milano: FrancoAngeli.

Martini, U. (2005). Management dei sistemi territoriali. Gestione e marketing delle destinazioni turistiche. Torino: Giappichelli.

Marzano, M., \& Castellini, M. (2018). The Reform of the Italian Ministry of Cultural Heritage: Implications for Governance of the Museum System. The Journal of Arts Management, Law, and Society, 48 (3), 206-220.

Montella, M. (2003). Musei e beni culturali, verso un modello di governance, Milano: Electa-Mondadori.

Montella, M. (2009). Valore e valorizzazione del patrimonio culturale storico. Milano: Electa-Mondadori.

Pencarelli T. \& Splendiani S. (2008). Il governo delle destinazioni e dei prodotti turistici: analisi di alcune esperienze, Mercati e Competitività, 2, 91-121.

Pezzoni, L., \& Vago, M. (2000). Musei italiani: il sistema vincente. La Rivista del Turismo, 5-6, 29-49.

Pine, J.B., \& Gilmore, J.H. (2000). L'economia delle esperienze. Milano: Etas Libri.

Rullani, E. (2008). L'economia della conoscenza nel capitalismo delle reti. Sinergie, 26 (76), 67-90.

Soren, B. J. (2009). Museum experiences that change. Museum Management and Curatorship, 24 (3), 233-251.

Thorelli, H.B. (1986). Networks: between market and hierarchies! Strategic Management Journal, 7(1), 37-51.

Vaccà, S. (1986). L'economia delle relazioni tra imprese: dall'espansione dimensionale allo sviluppo per reti esterne. Economia e Politica Industriale, 51, 48-86.

Vicari, S. (2008). Conoscenza e impresa. Sinergie, 26 (76), 43-66.

Zan, L. (a cura di). (1999). Conservazione e innovazione nei musei italiani. Management e processi di cambiamento. Milano: Etas Libri. 